\title{
The Effect of Theory of Planned Behavior and Environmental Concern on The Selection of Merries Brand Baby Diapers
}

\author{
Lidia Febrianti and Dudi Permana
}

\section{ABSTRACT}

This study analyzes the effect of theory of planned behavior and environmental concern to purchase intentions of diapers "Merries". The population of this study is mothers who have children that uses diapers and located in DKI Jakarta, with a total sample of 105 respondents. The data analysis method uses Structural Equation Model-Partial Least Square (SEM-PLS). The result of this study indicate is attitude, subjective norm, perceived of behavioral control and environmental concern affect positively but only perceived of behavioral control significantly affect towards purchase intentions.

Keywords: Theory of planned behavior, Environmental Concern, Purchase Intention.

\section{INTRODUCTION}

Garbage disposal is one of the causes of environmental damage caused by humans. Among them, the composition of waste in big cities like DKI Jakarta, the composition of disposable diaper waste ranks third at $12.9 \%$.

The increasing growth of the disposable diaper business has resulted in an increase in the consequences of waste generated from the use of its products. Therefore, demands in terms of business processes that prioritize environmental efficiency should be the focus of producers. In the current era, more and more consumers are aware of being environmentally friendly and manifested by real behavior in their consumption patterns.

PT KAO, as one of the manufacturers of Merries disposable diapers in Indonesia, implements a green marketing program as a form of its participation in environmental sustainability.

Based on the preliminary survey results of 30 respondents in April 2020, it is known that as many as $100 \%$ attitude variables, $90 \%$ subjective norm variables, $96.7 \%$ perceived behavioral control variables, and as many as $83.3 \%$ environmental concern variables were chosen by respondents as factors that influence their purchase intention of Merries brand so that in this study, there are 4 dominant factors that influence respondents in purchasing intention of Merries brand diaper products.
Published Online: February 4, 2021

ISSN: $2507-1076$

DOI: $10.24018 /$ ejbmr.2021.6.1.710

Lidia Febrianti

Master of Management, Mercubuana University, Jakarta, Indonesia.

(e-mail: lidia.febrianty@gmail.com)

Dudi Permana

Doctor of Philisophy, Mercubuana University, Jakarta, Indonesia.

(e-mail: dudi.permana@mercubuana.ac.id)

*Corresponding Author

\section{LITERATURE REVIEW}

\section{A. Theory of Planned Behavior}

TPB is a psychological model used to analyze consumer behavior and intentions [10]. According to this theory, individual behavior can be predicted by behavioral intention, which is an individual model (1) attitudes toward behavior, favorable or unfavorable evaluation of attractive behavior, (2) subjective norms, beliefs about certain people who are important to the individual. can approve or disapprove of behavior, and (3) control of people's perceived behavior, perception of ability to perform a given behavior.

\section{B. Attitude}

Attitude describes the tendency of a consumer to like an object. When an individual positively appreciates an action, then he has the will to do a certain action. Attitude towards a behavior formed by [1]:

1) Behavioral Belief, namely the belief that behavior will produce an output or belief in the consequences of doing certain behaviors.

2) Outcomes Evaluation / Evaluation of the Consequency, namely a person's evaluation of the output or evaluation of the consequences of behavioral beliefs.

\section{Subjective Norm}

Subjective norms are benefits that have a basis for belief which has the term normative belief. Normative belief is a belief in the understanding or disagreement of a person or group that affects an individual's behavior [7].

Hwang, Kim, \& Gulzar [5] argue that subjective norm shows an individual evaluating the people around him in certain behaviors. So, it can be concluded that subjective 
norm is the influence of behavior that comes from social influences such as family, relatives, colleagues and certain other people who become someone's support in making decisions.

\section{Perceived Behavioral Control}

Behavioral control is defined as an individual's understanding of doing an action based on past experiences and being able to find solutions when they face obstacles to their actions [7].

The more individuals perceive many supporting factors and few inhibiting factors to be able to perform a behavior, the greater the control they feel over the behavior and vice versa, the less the individual feels the supporting factors and many inhibiting factors to be able to perform a behavior, the individual will tend to perceive themselves as difficult to perform these behaviors. There are two factors to determine perceived behavioral control, namely control belief and perceived power [9].

\section{E. The Environmental Concern Concept}

Environmental concern is defined as a tool to identify environmentally friendly product purchasing behavior and can be a major factor in the consumer decision-making process [6].

Harahap [4] explains the dimensions of environmental concern, namely:

1) Balance of Nature, this dimension explains a person's belief that the natural balance is very vulnerable to damage due to human activities

2) Limit to Growth, this dimension of understanding that the limited resources that exist on earth

3) Anti-anthropocentrism, this is based on the view that nature meets the needs of not only humans but other creatures

4) Anti-exemptionalism, refers to the belief that human life is not free from natural rules / laws of nature

5) Eco-crisis, is the belief that humans cause harmful damage to the physical environment

\section{RESEARCH METHODOLOGY}

Based on existing theories and dimensions, the researcher makes a research framework.

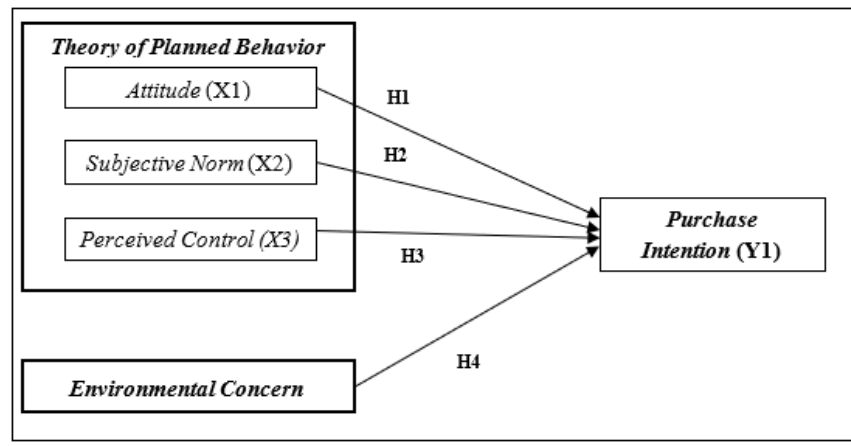

Fig. 1. Research Framework.

The population analyzed was young mothers whose children did not use Merries diapers. In this study, the number of question indicators was 21 , so the number of respondents was 21 question items multiplied by 5 equals to 105 respondents [3].

In this study, the authors used quantitative descriptive analysis, assisted by Partial Least Square (PLS) software.

\section{RESEARCH RESULT}

\section{A. Description of Respondents' Answers}

Descriptive statistics are used to interpret respondents' answers to the indicators of each variable. From the statistics obtained in this study, it can be explained that the 21 instrument items were submitted to 105 respondents

The tabulation results show that based on the number of children, it is dominated by respondents who have children who use disposable diapers amounting to 1 child as much as $81.9 \%$. Furthermore, the age of the most respondents was in the age range of 30-34 years as much as $43.8 \%$. Judging from the education in this study was dominated by respondents with $\mathrm{S} 1$ graduates as much as $78.1 \%$.

Furthermore, for jobs, the most respondents were employees both private / public as much as $65.7 \%$ and the highest income was in the range of Rp. 5,000,000-10,000,000 as much as $58.1 \%$. Meanwhile, the respondents' expenditure for buying disposable diapers was at most> Rp. 300,000 as much as $69.5 \%$. Most respondents buy disposable diapers at supermarkets / mini-markets as much as $56.2 \%$.

\section{B. Hypothesis Testing Result}

The results of hypothesis testing can be indicated by the $\mathrm{T}$ Statistic value where the recommended value must be above 1.96 .

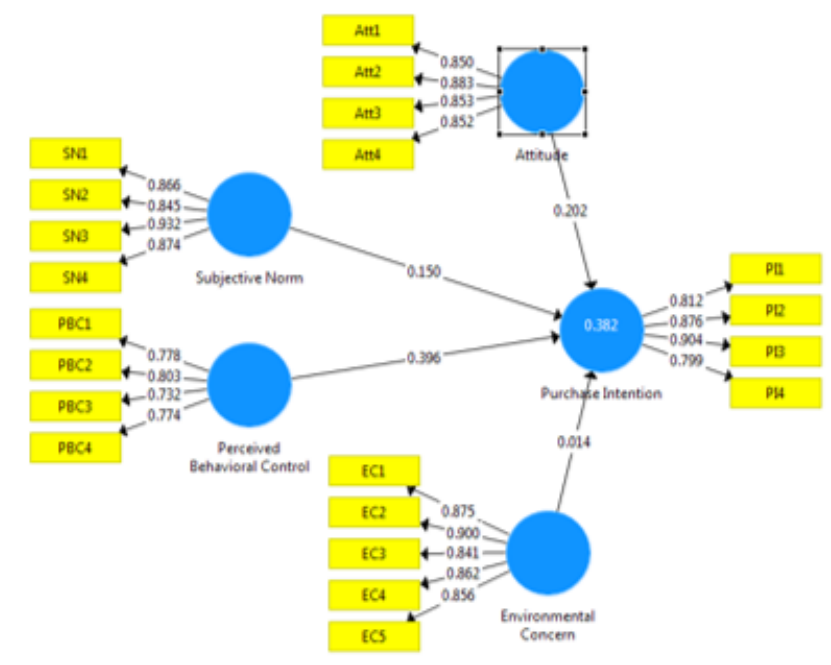

Fig. 2. Bootstrapping Results.

1) Even though attitude and purchase intention have a positive relationship, the results are not significant. This is due to the $\mathrm{T}$ statistic value obtained $\leq 1.96$ which is 1.472 , it can be concluded that the hypothesis ( $\mathrm{H} 1)$ is rejected where subjective norm is not significantly tested on purchase intention.

2) Although subjective norm and purchase intention have a positive relationship, the results are not significant. This is due to the $T$ statistical value obtained $\leq 1.96$ which is equal to 1.855 , so it can be concluded that the hypothesis (H2) is rejected where the attitude is not significantly tested towards purchase intention. 
3) Other results indicate a positive and significant relationship between perceived behavioral control and purchase intention by looking at the $\mathrm{T}$ statistical value obtained $>1.96$, which is 4,043 and a $P$ value $<0.05$, which is 0,000 , so it can be concluded that the hypothesis (H3) is accepted.

4) Although environmental concern and purchase intention have a positive relationship, the results are not significant. This is due to the $\mathrm{T}$ statistical value obtained $\leq 1.96$ which is equal to 1.156 , it can be concluded that the hypothesis (H4) is rejected where environmental concern is not tested significantly towards purchase intention.

\section{DISCUSSION}

\section{A. Effect of Attitude on Purchase Intention}

The results showed that the greater the attitude factor, the greater the purchase intention towards Merries products, and vice versa, where the smaller the attitude factor, the purchase intention towards Merries products will decrease. This result is in line with research by Verma \& Chandra [8] where the attitude factor has a positive influence on purchase intention. Even so, attitude does not have a significant impact on purchase intention. Attitude describes a person's judgment, feelings, and a relatively consistent tendency towards an object. The positive effect shows that a more positive attitude will tend to influence someone to buy Merries disposable diapers.

\section{B. Effect of Subjective Norms on Purchase Intention}

The results showed that the greater the subjective norm factor, the greater the purchase intention for Merries products, and vice versa, where the smaller the subjective norm factor, the lower the purchase intention for Merries products. This result is in line with research by Cheung \& To [2], where the subjective norm factor has a positive influence on purchase intention. Even so, subjective norms do not have a significant impact on purchase intention. Subjective norms describe the social influences that affect a person's behavior. The positive effect shows that the more positive subjective norm will tend to influence someone to buy Merries disposable diaper products. Many mothers want to provide the best for their children, including the need for disposable diapers that are used every day. This encourages many mothers to seek or consider the opinion or influence of others who are considered important and experienced in choosing the best products for their children.

\section{Effect Perceived Behavioral Control on Purchase Intention}

Based on the test results in this study, it shows that perceived behavioral control has a positive and significant effect on purchase intention. Perceived behavioral control describes the perception of supporting and inhibiting factors that affect the difficulty or ease of behaving. The results show that the more positive perceived behavioral control will tend to influence someone to intend to buy Merries brand disposable diapers significantly. This means that the more people feel the supporting factors compared to the inhibiting factors to be able to purchase Merries disposable diapers, the more control they feel over the purchase and vice versa.

\section{Effect Environmental Concern on Purchase Intention}

Based on the test results in this study, it shows that environmental concern has a positive but insignificant effect on purchase intention. Environmental concern describes a person's awareness of environmental issues and has a desire to address environmental problems that arise. The positive influence shows that an increasingly positive environmental concern will tend to influence someone to buy Merries disposable diapers. The existence of the "Merries Senyumkan Lingkungan" program has had an impact on awareness of the issue of waste accumulation and supports the program as a form of contribution in overcoming the bad consequences resulting from their consumption behavior. The proenvironmental brand image was generated from the program, thus encouraging purchase intentions of Merries disposable diapers.

\section{CONCLUSIONS}

The conclusion produced in this study shows that attitude, subjective norm and and do not have a significant impact on purchase intention. Meanwhile, perceived behavioral control have a significant impact on purchase intention.

Suggestions for companies to improve individual perceptions of their products by understanding purchase motivation which can be influenced by various factors, such as price, quality, product function, attractive promotions and other factors. Thus, individual attitudes are increasingly positive towards Merries which will have an impact on their purchase intentions.

The positive social influence on individual purchase intentions, it would be better if the company considered increasing communicative forum activities for mothers who use Merries so that it will open opportunities for mothers to get to know products, support each other and recommend Merries to other mothers based on their positive experiences even outside. forum. The company can also identify if there are complaints or their unfulfilled wishes from Merries products.

Companies need to better inform them about the proenvironmental program that is being implemented because it will have a positive impact on the buying interest of individuals who in this era have begun to switch to green consumption patterns. Program socialization can be done more intensely with virtual media such as social media.

\section{REFERENCES}

[1] Anggelina, J., \& Japarianto, E. (2014). Analysis of the Influence of Attitudes, Subjective Norms and Perceived Behavioral Control on Purchase Intention of SOGO Department Store Customers at Tunjungan Plaza Surabaya. Marketing strategy Journal, 2(1), 1-7.

[2] Cheung, M. F. Y., \& To, W. M. (2016). Service co-creation in social media: An extension of the theory of planned behavior. Computers in Human Behavior, 65, 260-266.

[3] Hair, J.F., Black, W.C., Babin, B.J., \& Anderson, R.E. (2010). Multivariate Data Analysis. Seventh Edition. Prentice Hall, Upper Saddle River, New Jersey.

[4] Harahap, L. S. (2018). Relationship between Self-Efficacy and Environmental Concerns in Communities Living on the River Deli. Sumatera Utara University.

[5] Hwang, J., Kim, I., \& Gulzar, M. A. (2020). Understanding the ecofriendly role of drone food delivery services: Deepening the theory of planned behavior. Sustainability (Switzerland), 12(4), 1-12. 
[6] Novita, N. (2020). The Influence of Green Perceived Knowledge and Environmental Concern on Eco-Friendly Behavior in Economics Education Students, University of Lampung (Universitas of Lampung). University of Lampung.

[7] Seni, N. N. A., \& Ratnadi, N. M. D. (2017). Theory of Planned Behavior To Predict Investment Intention. E-Journal of Economics and Business, Udayana University, 6(12), 4043-4068.

[8] Verma, V. K., \& Chandra, B. (2017). An application of theory of planned behavior to predict young Indian consumers' green hotel visit intention. Journal of Cleaner Production, 172, 1152-1162.

[9] Wikamorys, D. A., \& Rochmach, T. N. (2017). Application of Theory of Planned Behavior in Awakening Patients Intention to Perform Catarct Surgery. Jurnal Administrasi Kesehatan Indonesia, 5(1), 3240.

[10] Zhou, H., Romero, S. B., \& Qin, X. (2016). An extension of the theory of planned behavior to predict pedestrians' violating crossing behavior using structural equation modeling. Accident Analysis and Prevention, $95,417-424$ 